\title{
CHAGASIC MENINGOENCEPHALITIS IN THE IMMUNODEFICIENT
}

\author{
JAVIER LAZO*, ANTONIO CARLOS OLIVEIRA MENESES **, ADEMIR ROCHA **, MARCELO SIMÃO \\ FERREIRA**, JAIME OLAVO MARQUEZ**, EDMUNDO CHAPADEIRO**, EDISON REIS LOPES**
}

\begin{abstract}
Based on their own experience and on the literature, the authors compare the brain pathology due to HIV+ associated Trypanosoma cruzi reactived infection to that described for the natural history of the Chagas' disease (CD). The peculiar focal necrotizing chagasic meningoencephalitis (MECNF) which appears only in immunedeficient chagasics, especially when the deficiency is due HIV is a safe criterion for reactivation of CD. MECNF morphologic findings are unlike to those found either for some cases of acute phase CD or for chronic nervous form of $\mathrm{CD}$.
\end{abstract}

KEY WORDS: chagasic meningoencephalitis, encephalitis, AIDS, Trypanosoma cruzi, Chagas' disease.

\section{Meningoencefalite chagásica no imunodeficiente}

RESUMO - Baseados na experiência pessoal e nos dados da literatura, os autores comparam as alterações anatomopatológicas encefálicas resultantes da reativação da infecção pelo Trypanosoma cruzi, de paciente HIV+, com aquelas observadas e descritas na história natural da doença de Chagas (DC). A meningoencefalite chagásica necrosante focal (MECNF) que somente se desenvolve em tripanosomoticos imunodeficientes, especialmente quando a imunodeficiência é devida ao HIV, tem características peculiares e constitui parâmetro anatomopatológico seguro, de reativação da DC. Esta MECNF apresenta lesões diversas daquelas que podem ser observadas e que são descritas em casos da fase aguda e da forma nervosa crônica da DC.

PALAVRAS-CHAVE: meningoencefalite chagásica, encefalite, AIDS, Trypanosoma cruzi, doença de Chagas.

During the last decades, various events such as the use of cytostatic agents and immunosuppressors, the progress in organ transplantation and, especially, the advent of acquired immunodeficiency syndrome (AIDS) have set conditions for the reactivation of infection by Trypanosoma cruzi. This prompted some ${ }^{24}$ to revive the old concept of acute exacerbations of Chagas' disease (CD), proposed by Chagas in $1911^{3}$ but discarded later by himself $f^{4}$.

In 1994, we analyzed the main pathologic findings in 23 chagasic patients infected with human immunodeficiency virus (HIV), with or without AIDS $^{26}$. Following that paper many other addressed the topic ${ }^{2,5,7,9,11,18,21,27,28}$. From those reports and the others presented in meetings, 29 of 75 (38.6\%) patients with $T$. cruzi infection had reactivation involving the central nervous system (CNS).

The morphologic features of chagasic meningoencephalitis (CME) in patients with chronic CD accompanying AIDS is sometimes similar to those described for chagasics with other immunosuppressive conditions ${ }^{13}$. They are much alike the description by Queiroz in $1973^{25}$. The latter did not refer to immunosuppression. However, his patient was clinically diagnosed as having mycosis fungoides,

Curso de Pós-Graduação em Patologia Humana da Faculdade de Medicina do Triângulo Mineiro, Uberaba, MG e Centro de Ciências Biomédicas da Universidade Federal de Uberlândia, Uberlândia, MG: *Doutorando, ***Professor. Aceite: 4-novembro-1997.

Dr. Edison Reis Lopes - Curso de Pós-Graduação em Patologia Humana, Faculdade de Medicina do Triângulo Mineiro - Rua Getúlio Guaritá 130-38025-440 Uberaba MG - Brasil.FAX 55343126630.E-mail: lazo@ mednet.com.br 
nowadays a well-known T-cell lymphoma related with immunosuppression ${ }^{6}$. CME in some immunodeficient chagasic patients, especially when the immunodeficiency is due to HIV, has its own special features, which are clearly distinct from either acute ${ }^{3,30,31}$ or chronic ${ }^{16,20,22,29} \mathrm{CD}$ involving the CNS.

The present paper compares the morphological alterations of reactivated $T$. cruzi infection in brains of HIV+ patients with those classically described for natural history of CD.

\section{Brain morphology in acute chagasics}

Classical studies ${ }^{3,30}$, recent data ${ }^{8,10,14,16,20,22,29}$ and our experience indicate that some acute phase chagasics present with serious neurological manifestations. These acute chagasic patients develop CME including multifocal brain lesions in white and gray matters, accompanied by a diffuse lymphocytic leptomeningitis with few plasma cells, macrophages and polymorphonuclear leukocytes. The parenchymal CNS lesions, particularly in the deeper cortical layers as well as in the sub-cortical white matter, include perivascular inflammatory cell infiltrates in addition to foci of microglial proliferation, swollen oligodendrocytes and astrocytes, neuronophagy and small hemorrhages. The inflammatory infiltrates are usually more severe within the white matter and are sometimes accompanied with small foci of demyelination. Amastigote forms of $T$ cruzi are found within glial cells in most cases. Neuronal parasitism is scant or usually absent. Necrosis of the nervous tissue is minimal if it ever occurs.

\section{Brain morphology in chronic chagasics}

The great majority of the chagasic patients survive their acute disease, which gradually merges into the chronic phase. It is our experience that during the chronic phase chagasic patients may present with mild encephalitis with few inflammatory foci ${ }^{17}$. Those foci may either remain as such or be replaced by glial scars or completely disappear. Pittella ${ }^{22}$ has demonstrated foci with scant inflammatory cells without surrounding nervous tissue lesions in $6 \%$ of brains from chronic chagasic patients. In his opinion those might be residual lesions from the acute phase.

During chronic CD clinical CNS manifestations may be detected ${ }^{8}$ and anti-T. cruzi antibodies and auto-antibodies may also be found in the cerebro-spinal fluid ${ }^{15}$. In spite of these evidences, Pittella $^{22}$ admits that "no anatomical basis exists that might characterize the existence of chronic nervous form of CD".

We feel that detailed morphological studies of the CNS from chronic chagasic patients with close neurological follow-up is needed to prove or disprove an anatomical basis for the existence of a neurological form of chronic $\mathrm{CD}^{17}$.

\section{Brain morphology in immunodeficient chagasics}

The brains of immunodeficient chagasic patients, especially those with HIV infection, show an increased weight and volume with enlargement and flattening of the gyri and narrowing of the sulci. They present with softened, hemorrhagic and poorly limited areas ranging up to several centimeters in diameter involving both white and gray matters (Figs 1 and 2). It appears that white matter is the preferred site of involvement. The lesions are mostly located in the cerebral lobes and, less frequently, in the cerebellum and brain stem. To the best of our knowledge no basal ganglia lesions were ever described. Especially in the softened areas, microscopy shows meningoencephalitis with tendency to necrosis and hemorrhage (Fig 3). Encephalitis seems to be the primary lesion. Microglial nodules are found within the white and gray matters in nearly all cases. Edema, necrosis, recent or old focal hemorrhages and focal astrocytic gliosis, mostly within the white matter, are usually also found. In addition there are dense exudates of macrophages, lymphocytes and plasma cells and, to a lesser degree, neutrophilic granulocytes within the perivascular spaces. Vascular necroses are frequent but thrombosis seems to be rare. Amastigotes of T. cruzi (Fig 3, detail) are easily found within the glial cells and macrophages, especially around necrohemorrhagic areas, 


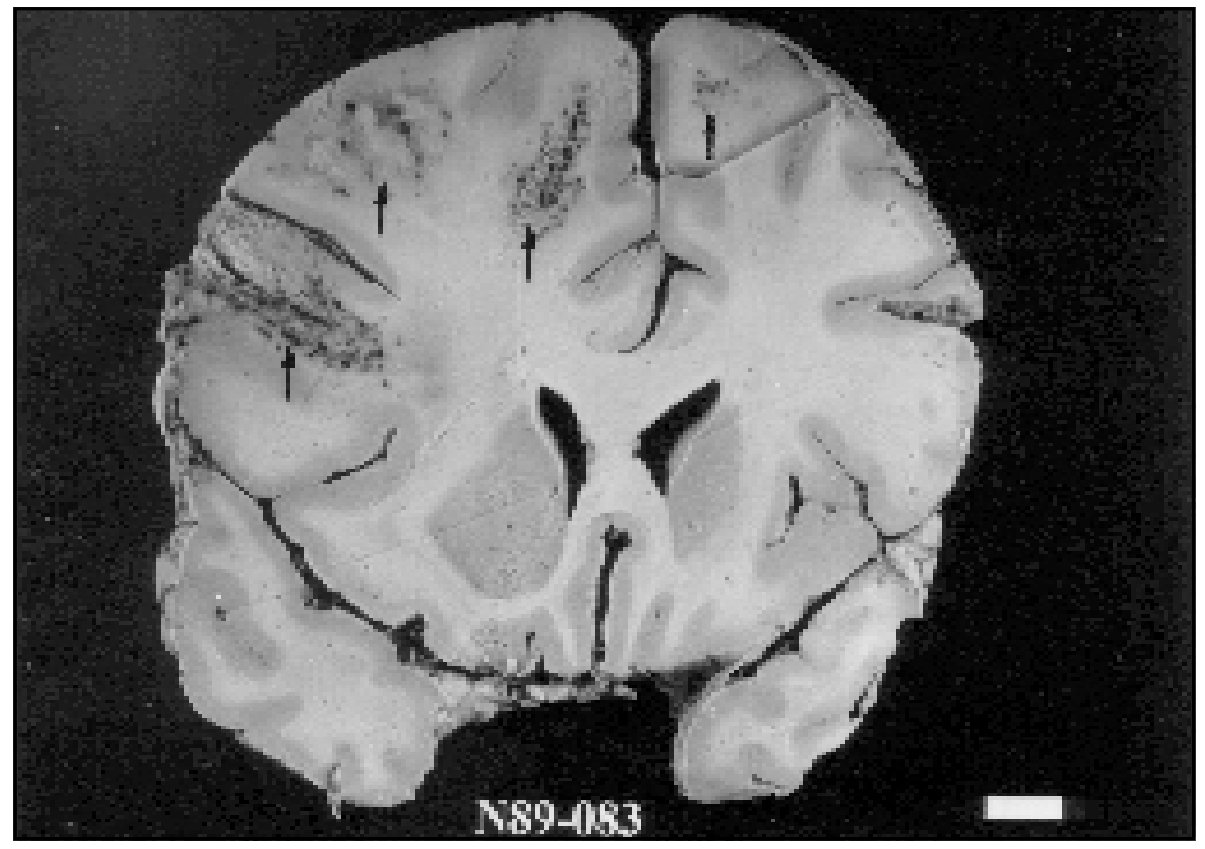

Fig 1. Frontal plane brain section showing poorly delimited necrohemorragic areas (arrows). Edema of the right cerebral hemisphere displacing the mid-line structures $($ bar $=1 \mathrm{~cm})$.

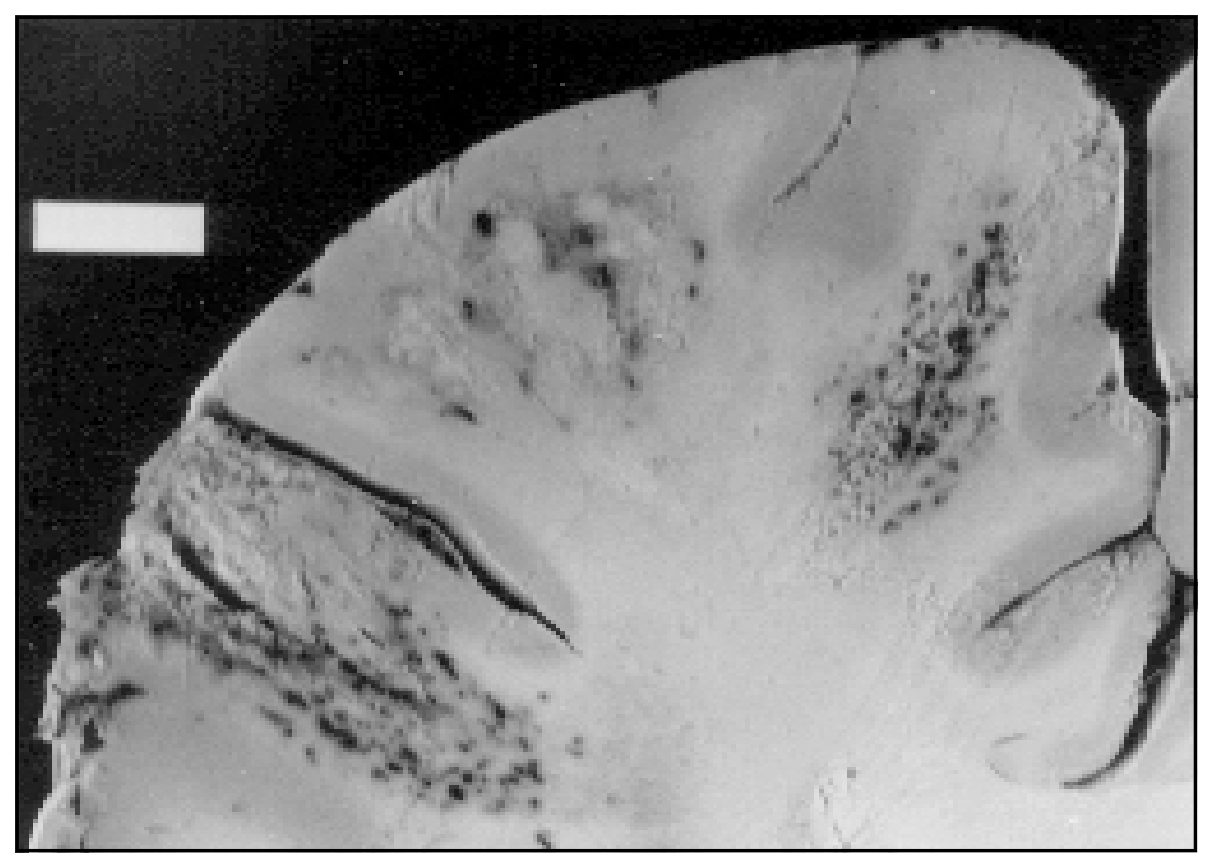

Fig 2. Detail of the Figure $1($ bar $=1 \mathrm{~cm})$. 


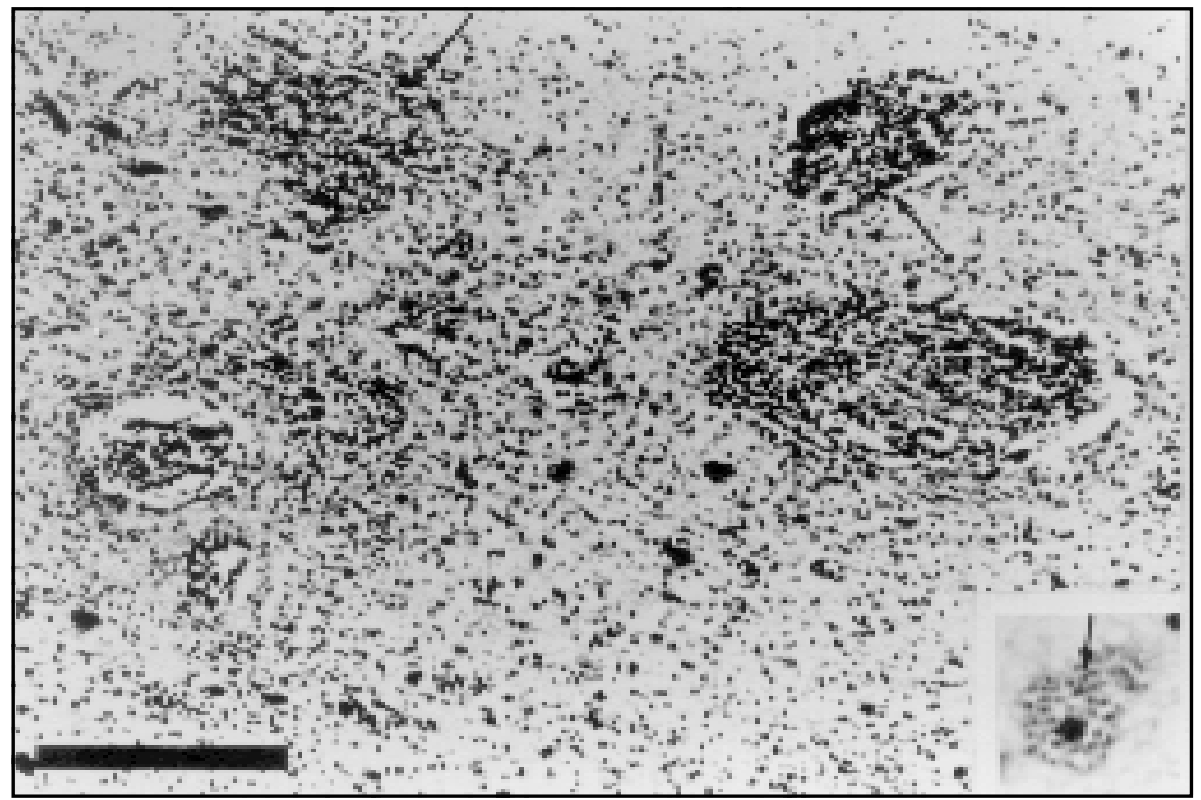

Fig 3. Histologic features of the white matter necrohemorragic lesions (arrows). Detail: T. cruzi amastigotes packed within a glial cell $(H-E$; bar $=122 \mu \mathrm{m})$.

around the blood vessels and free floating in the interstice. Neuronal parasitism is rare. Leptomeningitis is apparently an extension of the subjacent necrotic lesions. The leptomeningitis ranges from slight to moderate. Macrophages, lymphocytes, fewer plasma cells, and neutrophilic granulocytes, are found within the leptomeningeal lesions.

The foregoing findings, support the concept that CME in some immunodeficient chagasic patients, especially when the immunodeficiency is due to HIV, is different from the meningoencephalitis occurring either in the acute phase or in the nervous form of chronic phase of CD. It is a safe pathological indication of $\mathrm{CD}$ reactivation.

We propose the label focal necrotizing chagasic meningoencephalitis for the CME of HIV+ immunosuppressed patients herein described because of its similarity to focal necrotizing toxoplasmic encephalitis, as described, among others, by Post et al. ${ }^{23}$, Navia et al. ${ }^{19}$, Bertolli et al. ${ }^{1}$ and Lazo ${ }^{12}$.

Acknowledgment - We are grateful to Prof. J.K.Frenkel (Santa Fé, NM) for his help during the preparation of this article and for the support from the technical staff from Curso de Pós-Graduação em Patologia Humana da Faculdade de Medicina do Triângulo Mineiro (Uberaba, MG, Brazil).

\section{REFERENCES}

1. Bertoli F, Espinone Jr A, Fishback JL, Frenkel JK. A spectrum in the pathology of toxoplasmosis in patients with acquired syndrome. Arch Pathol Lab Med 1995;119:214-224.

2. Cardozo A, Mansilla M, Purstcher H, et al. Meningoencefalitis chagásica en el síndrome de inmunodeficiencia adquirida (SIDA): primer caso en Uruguay. Rev Med Uruguay 1992;8:214-217.

3. Chagas C. Nova entidade mórbida do homem: resumo geral de estudos etiológicos e clínicos. Mem Inst Oswaldo Cruz 1911;3:219-275.

4. Chagas C. Processos patogênicos da tripanosomíase americana. Mem Inst Oswaldo Cruz 1916;8:5-36.

5. Di Lorenzo GA, Pagano MA, Taratuto AL, Garau MI, Meli FJ, Pomsztein MD. Chagasic granulamatous encephalitis in immunosuppressed patients: computed tomography and magnetic resonance imaging findings. J Neuroimag 1996;6:94-97.

6. Franco M, Schmitt FC, Bacchi MM, Marigo C, Paes RP. Neoplasias do sistema hemilinfopoético. In Brasileiro Filho G, Pittella JEH, Pereira FEL, Bambirra EA, Barbosa AJA. (eds) Bogliolo patologia. 5.Ed. Rio de Janeiro: Guanabara Koogan, 1994:686-719. 
7. Gallo P, Fabião OM Neto, Suarez JMM, Borba RP. Acute central nervous system infection by Trypanosoma cruzi and AIDS. Arq Neuropsiquiatr 1992;50:375-377.

8. Jardim JO. Forma nerviosa crónica de la enfermedad de Chagas. Rev Neurol Arg 1977;3:429-438.

9. Jesus CAS, Soares CAS, Pasternak J. Síndrome da imudeficiência adquirida (AIDS) associada com infecção do sistema nervoso central pelo Trypanosoma cruzi. J Bras Patol 1995;31:110-113.

10. Jörg ME, Storino R, Sapino RV. Participación encefalopatica en la enfermedad de Chagas crónica: reflexiones derivadas de experiencia personal. Rev Soc Bras Med Trop 1994;27(Suppl 2):31-37.

11. Labarca JL, Acuña GL, Saavedra HC. et al. Enfermedad de Chagas en el síndrome de inmunodeficiencia adquirida: casos clinicos. Rev Med Chil 1992;120:174-179.

12. Lazo JE. Diagnóstico diferencial entre meningoencefalites toxoplásmica e chagásica em pacientes com infecção pelo vírus da imunodeficiência humana: ênfase às alterações morfológicas. Tese, Faculdade de Medicina do Triângulo Mineiro. Uberaba, 1995.

13. Leiguarda R, Roncoroni A, Taratuto Al, et al. Acute CNS infection by Trypanosoma cryzi (Chagas' disease) in immunosuppressed patients. Neurology 1990;40:850-851.

14. Lopes ER, Chapadeiro E, Tafuri WL, Prata AR. Doença de Chagas. In Brasileiro Filho G, Pittella JEH, Pereira FEL, Bambirra EA, Barbosa AJA, (eds). Bogliolo patologia. 5. Ed. Rio de Janeiro: Guanabara Koogan, 1994:1103-1124.

15. Marquez JO. Imunopatologia do líquido cefalorraqueano na doença de Chagas. Tese, Faculdade de Medicina de Ribeirão Preto. Ribeirão Preto, 1979.

16. Marquez JO. Forma nervosa da doença de Chagas: aspectos históricos e atuais. Rev Soc Bras Med Trop 1994;27:(Suppl 2):16-21.

17. Meneses ACO, Lopes ER, Chapadeiro E. Estudo anatomopatológico sistematizado de encéfalos de chagásicos crônicos falecidos subitamente. Rev Inst Med Trop São Paulo 1988;30:441-442.

18. Metze K, Maciel JA. AIDS and Chagas' disease. Neurology 1993;43:447-448.

19. Navia BA, Petito CK, Gold JWM, Cho E, Jordan BD, Price RW. Cerebral toxoplasmosis complicating the acquired immune deficiency syndrome: clinical and neuropathological findings in 27 patients. Ann Neurol 1986;19:224-238.

20. Nóbrega JPS. Estudo crítico das manifestações neurológicas descritas por Carlos Chagas na tripanossomíase cruzi. Rev Soc Bras Med Trop 1994;27(Suppl 2):22-27.

21. Pimentel PCA, Handfas BW, Carmignani M. Trypanosoma cruzi meningoencephalitis in AIDS mimicking cerebral metastases: case report. Arq Neuropsiquiatr 1996;54:103-106.

22. Pittella JEH. Central nervous system involvement in Chagas'́ disease: an updating. Rev Ins Med Trop São Paulo 1993;35:111-116.

23. Post DMJ, Chan JC, Hensley GT, Hoffman TA, Moskowitz LB, Lippmann S. Toxoplasma encephalitis in Haitian adults with acquired immunodeficiency syndrome: a clinical-pathologic-CT correlation. AJR 1983;140:861-868.

24. Prata A. Chagas' disease. Infect Dis Clin North Am 1994;8:61-76.

25. Queiroz AC. Tumor-like of the brain caused by Trypanosoma cruzi. Am J Trop Med Hyg 1973;22:473-476.

26. Rocha A, Meneses ACO, Da Silva AM, et al. Pathology of patients with Chagas' disease and acquired immunodeficiency syndrome. Am J Trop Med Hyg 1994;50:261-268.

27. Sartori AMC, Lopes MH, Caramelli B, et al. Simultaneous occurence of myocarditis and reactivated Chagas' disease in a patients with AIDS. Clin Infect Dis 1995;21:1297-1299.

28. Storino R, Freilij H. Asociación de enfermedad de Chagas y síndrome de imunodeficiência adquirida. In Madoery RJ, Madoery C, Cámera MI (eds). Actualizaciones en la enfermedad de Chagas. Cordoba 1992:243-248.

29. Tafuri WL. Anatomia patológica da forma nervosa central da fase crônica da doença de Chagas. Rev Soc Bras Med Trop 1994;27(Suppl 2):83-85.

30. Vianna G. Contribuição para o estudo da anatomia patológica da "Moléstia de Carlos Chagas" (Esquizotripanoze humana ou tireoidite parasitária) Mem Inst Oswaldo Cruz 1911;3:276-293.

31. Villela E, Villela E. Elementos do sistema nervoso central parasitados pelo Trypanosoma cryzi. Mem Inst Oswaldo Cruz 1932;26:77-82. 